\title{
Penerapan Teknik Antecedent Control untuk Meningkatkan Toilet Training pada Anak dengan Masalah Konstipasi
}

\author{
Nurul Annisa', Mayke S. Tedjasaputra ${ }^{2}$ \\ ${ }^{1,2}$ Fakultas Psikologi, Universitas Indonesia, Indonesia
}

\begin{tabular}{l}
\hline Info Artikel \\
\hline Sejarah Artikel: \\
Diterima \\
06 November 2019 \\
Direview \\
08 Februari 2020 \\
Disetujui \\
24 Februari 2020 \\
Dipublikasikan \\
27 Februari 2020 \\
\hline Keywords: \\
Antecedent Control; \\
Buang Air Besar; \\
Konstipasi, \\
Toilet Training
\end{tabular}

\begin{abstract}
Abstrak
Abstrak. Konstipasi merupakan masalah yang sering dijumpai pada anakanak. Anak dengan masalah konstipasi seringkali merasa sakit pada saat buang air besar $(B A B)$ sehingga berupaya untuk menghindari proses $B A B$ di toilet. Hal ini berdampak terhadap kemampuan toilet training anak. Penelitian ini bertujuan untuk menguji efektivitas program intervensi dengan teknik modifikasi perilaku antecedent control untuk meningkatkan frekuensi buang air besar di toilet pada anak dengan masalah konstipasi. Penelitian ini menggunakan metode single case subject $A-B$ with follow-up design dengan partisipan penelitian adalah seorang anak perempuan berusia 3 tahun 4 bulan yang mengalami konstipasi. Penelitian ini dilakukan sebanyak 8 sesi dan berlangsung selama 40 menit setiap sesi. Hasil penelitian menunjukkan bahwa teknik antecedent control dapat meningkatkan frekuensi perilaku buang air besar di toilet pada anak dengan masalah konstipasi.
\end{abstract}

\section{Application of Antecedent Control Techniques to Improve Toilet Training in Children with Constipation Problems}

\begin{abstract}
Constipation is common problem in children. Children who have constipation problems often feel pain during defecation, thus they are attempting to avoid the process of defecation in the toilet. It has an impact on the ability of children's toilet training. This study aimed to examine the effectiveness of intervention programs through behavior modification techniques, antecedent control to increase the frequency of bowel movements in the toilet for children who have constipation problems. This study uses a single case subject $A B$ with follow-up design which is a girl aged 3 years and 4 months who has constipation problems. This research was conducted in 8 sessions and lasted for 40 minutes each session. The result shows that antecedent control technique can increase the bowel movement for children who have constipation problems.
\end{abstract}

\footnotetext{
*Alamat korespondensi:

[Kampus Baru UI Depok, Jawa Barat - I6424, Indonesia]

[nurul.annisa72@ui.ac.id, 2maykeui@gmail.com]
} 


\section{Pendahuluan}

Konstipasi didefinisikan sebagai kondisi sulit buang air besar (BAB) secara teratur, tidak bisa benarbenar tuntas, atau tidak bisa sama sekali (ICD-I0, 20I6). Gejala ini lazim dijumpai pada anak-anak. Menurut Arnaud (2003), dikatakan konstipasi apabila terjadi penurunan frekuensi BAB (lebih dari 3 kali sehari atau kurang dari 2 kali seminggu) yang diikuti dengan kesulitan dalam mengeluarkan feses dan konsistensi feses yang keras, kering, dan/ atau kecil. Adanya upaya mengedan saat BAB, menurunnya volume feses, perasaan tidak tuntas saat $B A B$, atau tergantung pada penggunaan laksatif untuk mempertahankan $B A B$ yang normal merupakan gambaran dari konstipasi (Toner \& Claros, 2012).

Pola BAB pada anak dipengaruhi oleh fungsi organ, sistem saraf, pola makan, dan usia (Tehuteru, Hegar, \& Firmansyah, 200I). Apabila anak memiliki fungsi organ dan sistem saraf yang normal, maka pola makan akan sangat berperan dalam kejadian konstipasi. Kebiasaan mengkonsumsi makanan mengandung banyak serat umumnya menunjukkan kecilnya kejadian konstipasi. Selain faktor tersebut, faktor asupan cairan juga memiliki kontribusi terhadap kejadian konstipasi (Potter \& Perry, 2005). Hal ini dikarenakan serat tinggi tanpa asupan cairan tidak dapat merangsang lambung dalam memproses makanan dan meningkatkan pengeluaran feses. Asupan cairan yang cukup dalam tubuh membantu metabolisme saluran cerna (Ötles \& Ozgoz, 20l4). Anak yang memiliki cukup asupan cairan dalam tubuh berpeluang lebih kecil untuk mengalami konstipasi (Chan \& Chan, 20I0). Hasil penelitian Comas Vives et al. (2005) pada anak usia 4 bulan sampai I5 tahun juga menunjukkan bahwa konsumsi cairan (air dan jus) mengurangi resiko kejadian konstipasi. Oleh karena itu, individu yang mengalami konstipasi tidak cukup jika hanya mengkonsumsi makanan tinggi serat tanpa asupan cairan yang memadai.

Konstipasi dapat berdampak negatif terhadap kualitas hidup anak maupun keluarga (Van Ginkel et al., 200I). Anak dengan masalah konstipasi seringkali merasa sakit pada saat BAB. Hal ini membuat anak menunda pembuangan feses yang semakin meningkatkan rasa sakit ketika BAB dan memunculkan pola yang berulang sehingga semakin memperparah masalah konstipasi yang dialami (Wyllie, 2004; Taubman, Blum, \& Nemeth, 2003). Konstipasi juga dapat mempengaruhi kemampuan toilet training anak, terutama pada anak yang baru mulai dilatih toilet training. Penelitian yang dilakukan oleh Blum, Taubman, dan Nemeth (2004) menemukan bahwa anak yang merasa sakit ketika $B A B$ umumnya menghindari proses $B A B$ di toilet. Anak usia toddler umumnya menghindari penggunaan toilet saat $B A B$ dengan melakukan $B A B$ sambil berdiri dan menyilangkan kaki yang diinterpretasikan keliru oleh orang tua sebagai mengejan (Leoning-Baucke, 2005).

Toilet training merupakan salah satu kemampuan yang penting untuk dilatih pada anak untuk menjaga kesehatan dan kebersihan diri (Greer, 20I3). Melatih kemampuan toileting juga dapat menghindari anak dari kejadian yang tidak diinginkan ketika orang lain melihat atau memegang alat kelaminnya saat membantu anak membersihkan diri (Greer, 2013). Vermandel, VanKampen, Van Gorp, \& Wyndaele (2007) menyatakan bahwa keterampilan toilet training berdampak bagi kehidupan anak dan orang tua. Bagi orang tua, ketidakmampuan toilet training anak mempengaruhi biaya pengeluaran, tingkat stress, dan frustasi orang tua. Lebih lanjut, anak akan merasa malu saat berada di lingkungan sosial, ketergantungan yang berlebihan terhadap orang tua, dan memengaruhi kesiapan prasekolah.

Beberapa intervensi telah dilakukan sebagai langkah preventif maupun kuratif untuk masalah konstipasi. Penelitian yang dilakukan oleh Kuhl et al. (2009) terhadap anak usia 3-II tahun menggunakan intervensi perilaku (toilet training, rekomendasi konsumsi serat dan cairan, dan psikoedukasi orang tua) menunjukkan adanya peningkatan BAB dan konsumsi cairan secara signifikan. Pada tahun 2010, Kuhl et al. melakukan penelitian terhadap anak usia 4-12 tahun dengan intervensi yang lebih spesifik melibatkan catatan medis partisipan dan kelompok kontrol. Hasil penelitian menunjukkan peningkatan yang tinggi pada perilaku konsumsi cairan dan frekuensi BAB pada kelompok yang mendapatkan intervensi dibandingkan dengan kelompok kontrol. 
Di Indonesia, penelitian yang menguji efektivitas suatu program intervensi terhadap masalah konstipasi pada anak masih sulit ditemukan. Kadim dan Endyarni (20II) melakukan penelitian dengan memberikan intervensi terapi pijat pada anak usia 2-I4 tahun yang mengalami masalah konstipasi. Hasil penelitian menunjukkan peningkatan frekuensi BAB dan konsistensi feses menjadi lebih lembut pada anak setelah mendapatkan terapi pijat selama 2 bulan. Namun, penelitian ini tidak menggunakan intervensi perilaku seperti peningkatan konsumsi serat dan cairan atau toilet training. Penelitian lain yang menggunakan program intervensi dilakukan oleh Rosliany (2016) terhadap pasien imobilitas akibat fraktur untuk mencegah terjadinya konstipasi dengan bentuk intervensi berupa pemberian asupan cairan. Hasil penelitian menunjukkan bahwa minum air putih dapat mencegah terjadinya konstipasi dan menghasilkan konsistensi feses yang ideal pada subjek penelitian. Namun, karakteristik partisipan dalam penelitian tersebut adalah pasien dewasa, bukan anak-anak yang mengalami konstipasi.

Program intervensi perilaku atau modifikasi perilaku memiliki banyak teknik untuk diterapkan, salah satunya adalah teknik antecedent manipulation atau antecedent control. Teknik antecedent control adalah strategi yang melibatkan manipulasi lingkungan dan kondisi untuk meningkatkan respon yang diinginkan atau mengurangi perilaku yang tidak diinginkan (Miltenberger, 20I2). Penerapan teknik antecedent control dapat dilakukan dengan menyediakan anteseden stimulus dari target perilaku. Strategi yang dapat digunakan adalah meningkatkan jumlah konsumsi air dengan pertimbangan bahwa asupan cairan merupakan salah satu anteseden stimulus yang muncul dari kejadian konstipasi. Kontrol antesedan lain yang dapat diterapkan adalah dengan menambahkan kursi sebagai pijakan kaki selama proses BAB. Posisi ini membuat kaki menekan bagian perut dan membuka saluran rectum dengan sempurna sehingga membantu proses pengeluaran feses (Sikirov, 2003).

Toilet training merupakan salah satu kemampuan yang penting untuk dilatih pada anak. Munculnya kejadian konstipasi dapat mempengaruhi kemampuan toilet training karena rasa sakit yang dirasakan ketika BAB membuat anak menghindari proses BAB di toilet. Maka dari itu, penelitian ini bertujuan untuk menguji efektivitas program intervensi dengan teknik modifikasi perilaku antecedent control dan token economy untuk meningkatkan frekuensi buang air besar di toilet pada anak dengan masalah konstipasi.

\section{Metode}

Pada penelitian ini, variable terikat adalah kemampuan toilet training untuk melakukan $B A B$, sedangkan variabel bebas adalah intervensi modifikasi perilaku menggunakan teknik antecedent control. Definisi operasional dari kemampuan toilet training adalah perilaku masuk ke toilet, membuka celana, dan duduk di kloset untuk BAB. Perilaku yang tidak termasuk toilet training adalah melakukan BAB di toilet setelah lebih dulu mengeluarkan feses di celana. Stimulus anteseden yang dikontrol dalam penelitian ini adalah frekuensi minum air putih dan posisi duduk di toilet. Stimulus anteseden tersebut dipilih berdasarkan analisis fungsi perilaku (functional behavioral assessment). Berikut hasil dari functional behavioral assessment perilaku BAB pada $\mathrm{L}$. 
Tabel I.

A-B-C Perilaku Buang Air Besar pada L

\begin{tabular}{|c|c|c|}
\hline Antecedents & Behavior & Consequences \\
\hline $\begin{array}{lll}\text { I. } & \mathrm{L} & \text { kurang }\end{array}$ & \multirow{3}{*}{ Perilaku BAB di celana } & \multirow{3}{*}{$\begin{array}{l}\text { 1. Dibiarkan oleh ibu dan } \\
\text { nenek } \\
\text { 2. Kurang merasakan sakit } \\
\text { saat BAB } \\
\text { 3. Lebih mudah untuk } \\
\text { mengejan }\end{array}$} \\
\hline $\begin{array}{l}\text { mengkonsumsi air } \\
\text { sehingga mengalami } \\
\text { konstipasi }\end{array}$ & & \\
\hline $\begin{array}{l}\text { 2. Posisi BAB di toilet } \\
\text { tidak membantu } \\
\text { melancarkan proses } \\
\text { BAB }\end{array}$ & & \\
\hline
\end{tabular}

Partisipan dalam penelitian ini berjumlah satu orang dengan inisial $L$, anak perempuan yang berusia 3 tahun dan mengalami konstipasi. Sebelumnya, $L$ telah melakukan konsultasi psikologis terkait dengan kemampuan toileting untuk melakukan $B A B$. L sudah mampu menggunakan toilet untuk keperluan buang air kecil, namun belum menggunakan toilet untuk $B A B$. $L$ sudah menyadari keinginannya untuk $B A B$ namun lebih memilih untuk $B A B$ di celana sambil berdiri di pojok ruangan daripada menggunakan toilet. Perilaku $B A B$ di celana diinterpretasikan orang tua sebagai posisi nyaman untuk $L$ melakukan $B A B$ karena memudahkan $L$ untuk mengejan. $L$ memiliki pola $B A B$ yang tidak teratur bahkan $L$ pernah tidak $B A B$ dalam kurun waktu 5 hari berturut-turut. Orang tua sudah membawa $L$ ke dokter spesialis anak dan didiagnosa mengalami konstipasi. Berdasarkan hasil wawancara dengan orang tua, $L$ rutin mengkonsumsi sayur dan buah, namun konsumsi air mineral masih sangat minim, kurang lebih $600 \mathrm{ml}$ dalam sehari. L hanya mengkonsumsi air mineral setelah makan dan jarang meminta minum diluar waktu tersebut.

Penelitian ini menggunakan desain penelitian single subject $A-B$ with follow-up design, yakni hanya melibatkan satu partisipan $(\mathrm{N}=\mathrm{I})$. Pengukuran dilakukan dalam 3 fase, yaitu fase baseline, fase intervensi, dan fase follow up. Pengambilan data baseline dilakukan sebanyak 10 sesi berturut-turut untuk melihat konsistensi dari perilaku BAB pada L. Sesi Intervensi dilaksanakan sebanyak 8 sesi dan berlangsung selama 40 menit setiap sesi tanpa melihat ada atau tidaknya perilaku BAB. Sementara itu, sesi follow up dilakukan sebanyak 2 kali, yaitu 2 minggu dan I bulan setelah intervensi berakhir, masing-masing selama 8 sesi. Hal ini dilakukan untuk melihat apakah perubahan yang dicapai selama program dapat dipertahankan setelah program usai (response maintenance). Penelitian ini sudah melalui proses kaji etik dan telah disetujui oleh Komite Etika Penelitian Fakultas Psikologi Universitas Indonesia.

Pada penelitian ini melibatkan teknik prompt, fading, dan token economy. Teknik prompt digunakan untuk membantu memunculkan respon yang diinginkan. Prompt diberikan sebelum atau saat perilaku terjadi untuk mengubah perilaku. Pelaksana memberikan verbal prompt, modeling prompt dan physical prompt. Pada saat initial teaching (sesi I) perilaku manipulasi yang mengajarkan posisi duduk di kloset. Pelaksana memberikan physical prompt berupa mengarahkan kaki dan badan L untuk melakukan kegiatan yang diminta. Physical prompt disertai dengan verbal prompt yang menjelaskan pada $L$ apa yang harus $L$ lakukan seperti "L, kakinya letakkan di atas kursi". Sesi I akan diberikan sebanyak 2 kali untuk memastikan $L$ mengetahui dengan benar posisi duduk yang diajarkan. Pada sesi 3, tipe prompt yang digunakan yaitu physical prompt dan verbal prompt. Physical prompt berupa mengarahkan kaki dan badan $L$ untuk melakukan kegiatan yang diminta disertai dengan verbal prompt yang menjelaskan pada $L$ untuk duduk dengan posisi yang telah diajarkan. Pada sesi 4 pelaksana akan mulai memberikan fading prompt dengan hanya memberikan verbal prompt tanpa physical prompt. Pada sesi 6 , fading prompt yang diberikan berupa verbal prompt delay. Verbal prompt delay dilakukan dengan menunda pemberian verbal prompt selama 5 hingga 10 detik jika tingkah laku yang diharapkan tidak muncul. Prompt juga diterapkan pada perilaku konsumsi air putih, yaitu verbal prompt dan fading prompt. 
Pada antecedent control, terdapat reinforcer yang diterima oleh anak jika anak berhasil mencapai perilaku yang diminta. Reinforcer yang digunakan adalah token economy untuk memperkuat perilaku yang diharapkan. Token adalah sesuatu yang diberikan pada L, segera setelah perilaku yang diharapkan muncul. Setiap token yang diterima oleh $L$ untuk perilaku yang diharapkan dapat diakumulasikan, kemudian dapat ditukar dengan back-up reinforcer.

Tabel 2.

Tahapan Intervensi

\begin{tabular}{|c|c|c|}
\hline Sesi & Tujuan & Metode \\
\hline \multicolumn{3}{|c|}{ Baseline } \\
\hline $1-10$ & $\begin{array}{l}\text { untuk mengetahui frekuensi } \\
\text { munculnya perilaku } B A B \text { pada } L\end{array}$ & Observasi dan wawancara \\
\hline \multicolumn{3}{|c|}{ Intervensi } \\
\hline $1-8$ & $\begin{array}{l}\text { L dapat melakukan posisi duduk } \\
\text { seperti yang dilatihkan dan } \\
\text { meningkatkan frekuensi konsumsi } \\
\text { air }\end{array}$ & $\begin{array}{l}\text { Pemberian prompt meliputi } \\
\text { physical prompt, modeling prompt, } \\
\text { verbal prompt, dan fading secara } \\
\text { bertahap. }\end{array}$ \\
\hline \multicolumn{3}{|c|}{ Follow-up } \\
\hline $\begin{array}{l}2 \text { minggu setelah } \\
\text { intervensi } \\
\text { I bulan setelah intervensi }\end{array}$ & $\begin{array}{l}\text { Melihat perubahan yang dicapai } \\
\text { selama program dan konsistensi } \\
\text { setelah program usai (response } \\
\text { maintenance) }\end{array}$ & Observasi dan wawancara \\
\hline
\end{tabular}

Kualitas keberhasilan program intervensi dalam penelitian ini memiliki derajat kesuksesan yang berbeda-beda yang dapat dilihat pada tabel 3. Metode analisis data yang digunakan dalam penelitian ini adalah teknik statistik deskriptif dengan menggunakan grafik. Analisis data didapatkan dengan membandingkan frekuensi perilaku BAB yang muncul sebelum intervensi (baseline) dan setelah diberikan intervensi (follow-up). Program dikatakan berhasil apabila $L$ dapat secara konsisten melakukan BAB di toilet.

Tabel 3.

\section{Derajat kesuksesan perilaku}

\begin{tabular}{|c|c|}
\hline Perilaku & Nilai \\
\hline BAB di celana sambil berdiri & $25 \%$ \\
\hline BAB di celana kemudian melanjutkan di toilet & $50 \%$ \\
\hline BAB di lantai toilet & $75 \%$ \\
\hline BAB di kloset toilet & $100 \%$ \\
\hline
\end{tabular}

\section{Hasil}

Secara keseluruhan, penelitian ini dilakukan selama 34 hari, yaitu 10 hari untuk sesi baseline, 8 hari untuk sesi intervensi, dan 14 hari untuk sesi follow up. Hasil pengukuran baseline selama 10 sesi menunjukkan bahwa $L$ belum menunjukkan perilaku $B A B$ di toilet dari total 5 kali kemunculan perilaku BAB. L terlebih dahulu BAB di celana baru kemudian dibawa ke toilet oleh nenek. Konsistensi feses juga cenderung keras, kecil seperti butiran-butiran, dan tidak dilakukan dengan tuntas. Jumlah air putih yang dikonsumsi oleh $L$ sebelum intervensi rata-rata $600-650 \mathrm{ml}$ per hari. 


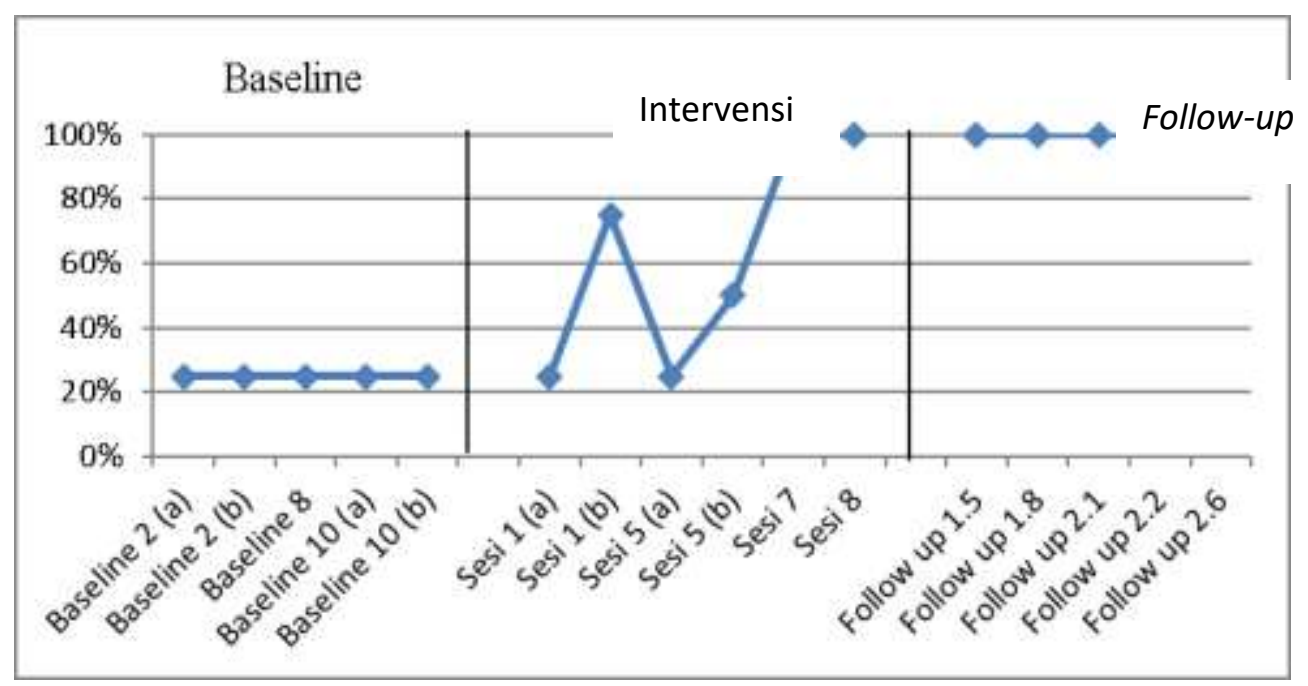

Gambar I. Perbandingan baseline, intervensi, dan follow up perilaku BAB

Pada fase intervensi terlihat adanya peningkatan frekuensi perilaku BAB di toilet yang ditunjukkan oleh $L$ sebagaimana yang terlihat dalam Gambar I. Pada hari pertama intervensi, $L$ masuk ke toilet untuk buang air kecil. Akan tetapi, disaat yang bersamaan $L$ juga BAB di lantai toilet. Setelah mengetahui hal tersebut, nenek membiarkan $L$ melanjutkan $B A B$ di lantai karena memang sudah 4 hari $L$ tidak $B A B$. Perilaku $B A B$ tersebut tidak dianggap sebagai perilaku yang sesuai target karena dilakukan di lantai toilet, bukan di kloset. Pada sesi selanjutnya sampai sesi ketiga intervensi, $L$ tidak menunjukkan perilaku $B A B$. Baru kemudian pada sesi keempat intervensi $L$ menunjukkan perilaku BAB sebanyak dua kali. Perilaku BAB pertama dilakukan di celana tanpa sepengetahuan nenek. Saat itu, nenek sedang melakukan pekerjaan rumah sehingga tidak memperhatikan aktivitas $B A B L$. Nenek baru mengetahui $L$ BAB setelah $L$ selesai dan meminta nenek untuk membersihkannya. Feses yang terdefikasi tergolong sedikit dengan konsistensi keras. Beberapa jam kemudian, $L$ kembali melakukan BAB di celana dan diketahui oleh nenek. Nenek kemudian mengajak $L$ ke toilet dan $L$ melakukannya tanpa penolakan. Jumlah dan konsistensi feses $L$ masih sedikit dan keras.

Selanjutnya pada sesi kelima, $L$ tidak menunjukkan perilaku $B A B$ hingga pada sesi keenam dan tujuh $L$ kembali menunjukkan perilaku $B A B$. Pada kedua sesi ini, $L$ menunjukkan adanya peningkatan dalam perilaku $B A B$ di toilet secara signifikan. $L$ sudah melakukan $B A B$ di toilet sesuai dengan target perilaku. Akan tetapi, $L$ masih membutuhkan dorongan eksternal untuk mau melakukannya. $\mathrm{Hal}$ ini terlihat pada sesi keenam dimana $\mathrm{L}$ menolak ketika diajak untuk menggunakan toilet oleh nenek. $L$ baru mau ke toilet setelah pelaksana mengingatkan $L$ tentang reward yang telah disepakati sebelumnya. Pada sesi ketujuh, $L$ tidak lagi menunjukkan perilaku menolak ketika diajak untuk $B A B$ di toilet dan sudah mau $B A B$ di toilet. Terkait dengan pola $B A B, L$ secara konsisten menunjukkan pola $B A B$ dengan frekuensi 3 sampai 5 hari sekali sebagaimana yang terlihat pada Gambar 2.

\begin{tabular}{|c|c|c|c|c|c|c|c|}
\hline \multicolumn{7}{|c|}{ APRIL 2019} & \multirow{2}{*}{$\begin{array}{l}\text { Keterangan: } \\
\text { Perilabu BAB mimed }\end{array}$} \\
\hline Min & Sen & Sel & Rab & $\mathrm{Kmm}$ & Jum & Sab & \\
\hline & $\mathrm{t}$ & 2 & 3 & (4) & 5 & 6 & $\triangle$ Penlaku BAB di boilet \\
\hline 3 & 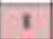 & 3 & (1) & I1 & $A$ & w & Sesi istervenai \\
\hline 14 & $\Delta$ & 16 & $\Delta$ & 18 & 19 & 20 & Seii Podh-aedt \\
\hline 21 & 22 & 23 & 24 & 25 & 29 & 27 & Sesi Follow up \\
\hline 28 & $A$ & 30 & & & & & \\
\hline
\end{tabular}

\begin{tabular}{|c|c|c|c|c|c|c|c|}
\hline \multicolumn{7}{|c|}{ XIF 2019} & \multirow{2}{*}{ Keterangan: } \\
\hline Min & Sen & set & Sab & Kam & Jum & Sab & \\
\hline & & & $T$ & 2 & 3 & 4 & \\
\hline 5 & $B$ & 7 & 8 & $A$ & 10 & 11 & \\
\hline 12 & 13 & 14 & $A$ & 19 & 17 & 15 & \\
\hline 19 & 20 & 21 & 22 & 23 & 24 & 25 & 1 \\
\hline 26 & 27 & 28 & 29 & 30 & 31 & & \\
\hline
\end{tabular}

Gambar 2. Kalender kemunculan perilaku BAB 
Konsistensi feses $L$ juga menjadi lebih lembut dari sebelumnya. Jumlah air yang dikonsumsi oleh $L$ meningkat menjadi $900 \mathrm{ml}$ sampai $1000 \mathrm{ml}$ per hari. Hal ini cenderung meningkat dari sebelum intervensi diberikan yang rata-rata hanya menghabiskan $600 \mathrm{ml}$ air per hari. Selain itu, selama proses penelitian mulai dari baseline hingga follow-up terlihat bahwa $L$ tidak menunjukkan perilaku $B A B$ secara teratur atau setiap hari. $L$ memiliki pola $B A B L$ sekitar 3 sampai 5 hari sekali.

\section{Pembahasan}

Hasil penelitian menunjukkan terdapat peningkatan persentase frekuensi perilaku BAB di toilet pada anak dengan masalah konstipasi menggunakan metode antecedent control. Terdapat beberapa faktor yang berkontribusi terhadap keberhasilan program penelitian ini. Salah satunya adalah penggunaan teknik antecedent control yang fokus pada kontrol anteseden. Strategi kontrol stimulus anteseden berupa posisi duduk di toilet dan peningkatan perilaku minum air merupakan strategi yang tepat untuk meningkatkan perilaku BAB di toilet pada L. Menurut Miltenberger (2012), teknik antecedent control efektif diberikan untuk memunculkan perilaku yang diinginkan karena teknik ini menyajikan situasi dan kondisi lingkungan yang mendukung kemunculan perilaku.

Posisi saat BAB memengaruhi proses pengeluaran BAB. Menurut Sikirov (2003), BAB lebih mudah dicapai dengan posisi jongkok karena sudut anorektal menjadi lebih lurus. Sudut anorektal yang lurus dapat membantu proses pengeluaran $B A B$ dengan lebih sempurna. Selain dengan posisi jongkok, sudut anorektal yang lurus juga dapat diperoleh dengan posisi $B A B$ di kloset duduk dengan menambahkan bangku kecil untuk mengganjal kaki selama proses defikasi.

Selanjutnya, dalam proses metabolisme, air berfungsi untuk melembutkan feses dan bertindak sebagai pelumas untuk membantu sisa metabolisme bergerak di sepanjang kolon sehingga membantu mencegah konstipasi. Bila tubuh tidak terhidrasi dengan baik maka proses pencernaan menjadi tidak sempurna sehingga dapat menimbulkan konstipasi (Swann \& Helffric dalam Rosliany, 2016).

Selain itu, pemberian prompt dan token economy juga berkontribusi terhadap efektivitas program intervensi. Kombinasi penggunaan physical, modeling, dan verbal prompt untuk mengajarkan posisi duduk di toilet dan memberi peringatan kepada $L$ untuk minum dinilai efektif karena pemberian prompt tersebut disesuaikan dengan tipe prompt yang paling tinggi tingkat bantuannya hingga yang paling rendah. Berdasarkan hasil penelitian dari Sabielny dan Cannella-Malone (20I4), most-toleast prompting merupakan strategi prompt yang efektif untuk pengajaran keterampilan sehari-hari pada anak.

Token economy yang digunakan juga membantu untuk memperkuat perilaku BAB di toilet pada $L$. Ketika $L$ diingatkan tentang reinforcement yang akan diperoleh apabila $L$ melakukan $B A B$ di toilet, $L$ menjadi lebih bersemangat dan terdorong untuk BAB di toilet. Menurut Miltenberger (20I2), efektifitas dari pemberian token ekonomi tergantung pada back up reinforcer karena reinforcer dipilih secara spesifik sesuai dengan kebutuhan partisipan dalam program intervensi. Selain itu, dukungan dan social reinforcer dari keluarga, terutama nenek, sangat membantu dalam meningkatkan perilaku BAB di toilet pada L. Menurut Skiner (dalam Feist \& Feist, 2008) perilaku yang sama yang disertai oleh respon yang sama dan adanya penguatan yang menyenangkan dari hasil merespon stimulus akan memperkuat munculnya perilaku dikemudian hari.

Selama proses intervensi, pengaruh nenek yang secara konsisten menjalankan intervensi juga memberikan dampak terhadap suksesnya intervensi. Nenek menjalankan prosedur modifikasi perilaku yang sama setiap harinya meskipun sesi bersama pelaksana program telah berakhir, misalnya setelah intervensi berakhir nenek tetap mengajari $L$ duduk di toilet menggunakan delay prompt. Peran pelaksana program juga turut memberi kontribusi dalam melatih $L$ menggunakan toilet untuk BAB. Selama ini $L$ tidak dilatih menggunakan toilet untuk BAB karena masalah konstipasi yang dialami. $L$ juga tidak dilatih untuk rajin mengkonsumsi air minum yang dapat 
mengurangi masalah konstipasinya. Hal ini membuat $L$ selalu menghindari penggunaan toilet untuk BAB.

Pelaksana memanipulasi antecedent bersamaan dengan pemberian prompt untuk mengajarkan $L$ posisi $B A B$ yang memudahkan proses $B A B$ sehingga mengurangi rasa sakit saat $B A B$ dilakukan. Dengan konsistensi $B A B$ yang lebih lembut dan proses $B A B$ yang lebih nyaman mendorong $L$ untuk menggunakan toilet saat BAB. Sebagaimana yang dijelaskan oleh Kazdin (2013) bahwa salah satu manfaat dari modifikasi perilaku adalah mengajarkan perilaku adaptif kepada anak. Selanjutnya, pemberian metode token ekonomi juga membuat $L$ menjadi lebih bersemangat dalam proses modifikasi perilaku. Emotional relation antara $L$ dengan pelaksana juga mempermudah jalannya program karena $L$ dapat menerima kehadiran pelaksana, begitupun sebaliknya.

Terkait dengan pola BAB yang yang ditunjukkan oleh L, yakni 3 sampai 5 hari sekali. Tehuteru, Hegar, dan Firmansyah (200I) menyebutkan bahwa pola BAB seorang anak dipengaruhi oleh faktor organik (fungsi organ dan sistem saraf), asupan makanan dan cairan, dan usia. Apabila anak menunjukkan kondisi faktor organik yang baik maka perlu diperhatikan asupan makanan dan cairan yang dikonsumsi oleh anak. Anak yang banyak makan makanan berserat akan memperlihatkan BAB yang lancar, tidak keras, dan teratur dibandingkan dengan anak yang tidak suka makan makanan berserat.

\section{Kesimpulan}

Berdasarkan data-data yang diperoleh dapat disimpulkan bahwa program modifikasi perilaku menggunakan teknik antecedent control dapat meningkatkan frekuensi perilaku BAB di toilet. Frekuensi perilaku $B A B$ di toilet pada $L$ yang awalnya tidak pernah dilakukan atau $0 \%$ meningkat menjadi $100 \%$ yaitu $L$ dapat menggunakan toilet untuk keperluan $B A B$ secara konsisten. Hal ini menunjukkan bahwa target keberhasilan program yang mensyaratkan $100 \%$ kemunculan perilaku tanpa bantuan telah tercapai. Perilaku ini sudah menetap pada $L$.

Penelitian ini memiliki beberapa kelemahan yang disarankan untuk diperbaiki di penelitian selanjutnya. Pertama, sebaiknya ada waktu minum yang ditentukan secara lebih spesifik, misalnya minum air sesudah bangun tidur, 30 menit sebelum makan, dan sebelum tidur. Hal ini dilakukan untuk memaksimalkan metabolisme dalam tubuh sehingga dapat bekerja lebih optimal. Metabolisme yang sehat dapat mengurangi masalah konstipasi yang dialami. Kedua, pemantauan asupan serat yang dikonsumsi oleh anak juga dapat dijadikan sebagai stimulus anteseden kontrol. Asupan serat yang merupakan salah satu faktor resiko terjadinya konstipasi dapat dilihat pengaruhnya terhadap munculnya kejadian konstipasi. Hal ini dilakukan untuk melihat secara lebih komprehensif faktor-faktor yang menjadi masalah bagi anak sehingga dapat dijadikan salah satu pilihan dalam merancang program. Ketiga, sebaiknya ada waktu untuk generalisasi perilaku target. $\mathrm{Hal}$ ini dilakukan untuk melihat apakah perilaku yang sudah terbentuk dapat diterapkan dalam semua setting lingkungan selain di rumah sendiri.

\section{REFERENSI}

Arnaud, M. J. (2003). Mild dehydration: a risk factor of constipation? European Journal of Clinical Nutrition, 57(S2), S88-S95. doi:10.1038/sj.ejcn. 1601907

Blum, N. J., Taubman, B., \& Nemeth, N. (2004). During Toilet Training, Constipation Occurs Before Stool Toileting Refusal. PEDIATRICS, I/3(6), e520-e522. doi:10.1542/peds.II3.6.e520

Chan, M. F., \& Chan, Y. L. (2010). Investigating factors associated with functional constipation of primary school children in Hong Kong. Journal of Clinical Nursing, 19(23-24), 3390-3400. doi:10.1 II I/j.1365-2702.2010.03362.x 
Comas, A. V., \& Polanco, I. A. (2005, April). Case-control study of risk factors associated with constipation. The FREl Study. In Anales de pediatria (Barcelona, Spain: 2003) (Vol. 62, No. 4, Pp. 340-345).

Feist \& Feist, (2008). Theories of personality; Seventh edition. USA: McGraw-Hill

Greer, Brian D. (20I3). An Evaluation of Toilet Training Procedures.Proquest Disertation.

ICD-I0-CM: International Classification of Diseases, IOth Revision, Clinical Modification. (2016).

Kadim, M., \& Endyarni, B. (2016). Manfaat Terapi Pijat pada Konstipasi Kronis Anak. Sari Pediatri, I2(5), 342. doi:10.14238/sp I2.5.20II.342-6

Kazdin, A.E. (2013). Behavior modification in applied settings (7thed.).Illinois: Waveland Press.

Kuhl, E. S., Felt, B. T., \& Patton, S. R. (2009). Brief Report: Adherence to Fluid Recommendations in Children Receiving Treatment for Retentive Encopresis. Journal of Pediatric Psychology, 34(I0), II65-II69. doi:I0.1093/jpepsy/jsp017

Kuhl, E. S., Hoodin, F., Rice, J., Felt, B. T., Rausch, J. R., \& Patton, S. R. (2010). Increasing Daily Water Intake and Fluid Adherence in Children Receiving Treatment for Retentive Encopresis. Journal of Pediatric Psychology, 35(I0), I I44-I I II. doi: I0.1093/jpepsy/jsq033

Loening-Baucke, V. (2005). Prevalence, symptoms and outcome of constipation in infants and toddlers. The Journal of Pediatrics, I46(3), 359-363. doi:10.1016/j.jpeds.2004.10.046

Miltenberger, Raymond G. (2012. Behavior Modification: Principles and Procedures. Fifth edition. USA: Wadsworth.

Ötles S., Ozgoz S., (2014). Health effects of dietary fiber. Acta Sci.Pol. Technol. Aliment. I3 (2), I9I-202 https://doi.org/10.17306/J.AFS.2014.2.8

Potter \& Perry, (2005).Buku ajar fundamental keperawatan: konsep, proses, dan praktik. Jakarta: EGC

Rosliany, N. Pengaruh Asupan Cairan Terhadap Kejadian Konstipasi dan Konsistensi Feses pada Pasien Imobilitas Akibat Fraktur di RSUP Fatmawati \& RSPAD Gatot Subroto. (2016).Tesis. Fakultas Ilmu Kesehatan Universitas Indonesia.

Sabielny, L. M. \& Cannella-Malone, H.I. (20I4). Comparison of prompting strategies on the acquisition of daily living skills. Education and Training in Autism and Developmental Disabilities, 49(I), I45-152

Sikirov, B.A. 2003. Comparison of straining during defecation in three positions. Dig Dis Sci. 48: I20|-5.

Taubman, B., Blum, N. J., \& Nemeth, N. (2003). Children Who Hide While Defecating Before They Have Completed Toilet Training. Archives of Pediatrics \& Adolescent Medicine, I57(I2), I190. doi:10.1001/archpedi.I57.12.1190

Tehuteru, E.S., Hegar, B., Firmansyah, A. (200I). Pola BAB pada Anak. Sari Pediatri. 200I;3:129-33

Toner, F., \& Claros, E. (2012). Preventing, assessing, and managing constipation in older adults. Nursing, 42(12), 32-39. doi:10.1097/0I.nurse.0000422642.83383.17

Van Ginkel, R., Buller, H. A., Boeckxstaens, G. E., Van der Plas, R. N., Taminiau, J. A., \& Benninga, M. A. (200I). The Effect of Anorectal Manometry on the Outcome of Treatment in Severe Childhood Constipation: A Randomized, Controlled Trial. PEDIATRICS, I08(I), e9-e9. doi:I0.1542/peds. I08.1.e9 
Vermandel, A., Van Kampen, M., Van Gorp, C., \& Wyndaele, J. (2007). How to toilet train healthy children? A review of the literature.Neurology and Urodynamics, 27, 162-166.

Wyllie R. Functional constipation. In: Kliegman, Behrman, Jenson, Stanton, editors. Nelson textbook of pediatrics. 18 ed. Philadelphia: Saunders Elsevier; 2004. p. 1565. 